\title{
ETOS KERJA PEREMPUAN PENAMBANG PASIR DALAM MEMBANTU MENINGKATKAN KESEJAHTERAAN KELUARGA (Studi di Kelurahan Ulunggolaka Kecamatan Latambaga Kabupaten Kolaka)
}

\author{
Iin Apriani ${ }^{1}$, Suharty Roslan ${ }^{2}$, Megawati A. Tawulo ${ }^{3}$ \\ ${ }^{123}$ Universitas Halu Oleo \\ Email: iinapriani0707@gmail.com, Suhartyroslan1967@gmail.com, Megawatiasrultawulo@gmail.com
}

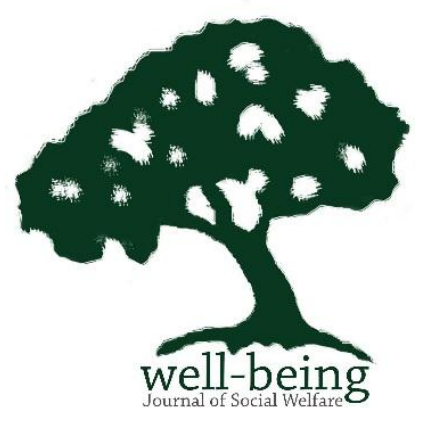

This study aims to determine the work ethics of women in the sand miners to help improve family welfare, and to find out the factors that influence the work ethics of women in the sand miners to help improve welfare. Family. This research method uses qualitative research methods with data collection techniques used are interviews, observation and documentation, data sources used are primary and secondary data sources, data analysis in this study is done with qualitative description and then analysis in accordance with power capabilities the researcher's reason to help the researcher's conclusions. The results showed that: the work ethic possessed by women sand miners, namely: a timely attitude in which a trait or ability possessed by a person or woman who mines sand, honesty means there is a matching of words with conscience and with reality or reality, an attitude of willingness to cooperate the attitude where the individuals concerned have the same interests and awareness, and the simplicity of where to live and focus on what is really needed. As for the factors that influence the work ethic of women sand miners in Kelurahan Ulunggolaka: Religion is a value that will influence or determine the lifestyle of its adherents, Culture in which regulates so that each individual understands what must be done and to regulate human behavior in interaction , Environmental conditions which include the condition of natural resources such as land, water and where can also be interpreted into everything that is around humans, and as for the Economic Structure which is used to show the composition or composition of the economic sector in an economy. Also helps to improve family welfare where the work is done by women sand miners to meet the needs of family life.

Keywords: work ethic, women, sand miners

\section{PENDAHULUAN}

Kehidupan keluarga di masyarakat sekarang ini, masih banyak keluarga yang belum terpenuhi Kesejahteraannya seperti dilihat Kelurahan Ulunggolaka Kecamatan Latambaga, adapun yang melakukan pekerjaan penambang pasir Yaitu 28 orang para isteri dalam membantu suami untuk memenuhi kebutuhan atau meningkatkan kesejahteraan keluarganya Misalnya kesejahteraan ekonomi yang belum terpenuhi karena pendapatan suami rendah, tidak mencukupi kebutuhan pokok, Anak yang masih bersekolah yang harus di biayai. Permasalahan seperti itu akan mempengaruhi tingkat kesejahteraan sosial dan kesejahteraan dalam keluarga. Santoso ( Dalam Elisa 1:2015).

Sebenarnya pekerjaan penambang pasir adalah pekerjaan yang lazim dilakukan oleh laki-laki namun, karena kebutuhan keluarga yang kurang, mengharuskan mereka untuk menggeluti pekerjaan sebagai penambang pasir demi membantu meningkatkan kesejahteraan keluarga Hal ini bukan tanpa alasan lakilaki mempunyai fisik yang lebih kuat bila dibanding perempuan sedangkan akses dari penambangan pasir dilakukan tidak terlalu jahu dan menanjak dari tempat pengumpulan pasir-pasir tersebut untuk kemudian diambil oleh pengepul pasir yang setiap hari ke sana untuk mengambil dan 
membayar pasir-pasir tersebut kepada para penambang Mereka yang bekerja di sana merupakan warga yang tinggal di Kelurahan Ulunggolaka, Kecamatan Latambaga terletak di daerah yang sangat dekat dengan sungai, sehingga warga yang bekerja sebagai penambang pasir banyak yang berasal dari kelurahan tersebut utamanya perempuan penambang pasir Alasan mereka menjalankan pekerjaan sebagai penambang pasir di samping letaknya yang sangat dekat, juga dikarenakan sudah dilakukan sejak lama dan penghasilan dari pekerjaan penambang pasir yang dapat menjanjikan, baik itu penghasilan utama maupun penghasilan tambahan.

\section{METODE PENELITIAN}

Penelitian ini dilaksanakan Di

Kelurahan Ulunggolaka, Kecamatan Latambaga, Kabupaten Kolaka. Penentuan Informan dalam penelitian ini, menggunakan teknik purposive sampling, yaitu pemilihan informan dengan pertimbangan tertentu, dengan anggapan bahwa Informan paling mengerti tentang informasi yang peneliti harapkan sehingga memudahkan peneliti menjelajahi objek dan situasi sosial tertentu.Adapun Informan dalam penelitian ini adalah :Perempuan Penambang Pasir Orang, Suami Dari Perempuan Penambang Pasir, Lurah Ulunggolaka dan Oprator Pelayanan Kelurahan Ulunggolaka dalam penelitian ini.

teknik pengumpulan data yang di gunakan adalah sebagi berikut :Jenis data. Yaitu Data kualitatif Data kuantitatif adapun sumber data Sumber datayaitu Data primer dan Data sekunder. dalam penelitian. Teknik pengumpulan data dalam penelitian ini adalah sebagai berikut:Wawancara, dan Dokumentasi.

Teknik analisis data ini menggunakan teknik analisis deskripti kualitatif, setelah data primer dan data sekunder di peroleh. Dan kemudian di kategorikan tahap berikutnya dan memeriksa keabsahan serta menafsirkannya dengan analisis sesuai dengan kemampuan daya nalar peneliti untuk membantu kesimpulan peneliti.

\section{HASIL DAN PEMBAHASAN}

\section{Etos kerja Perempuan Penambang} Pasir Di Kelurahan Ulunggolaka.

Etos kerja perempuan merupakan semangat kerja yang di milikinya mampu memberikan kehidupan yang lebih baik, semangat kerja perempuan penambang pasir mampu memenuhi kebutuhan dalam keluarga di mana seperti kita lihat koadrat seorang perempuan dalam keluarga mempunyai tugas utama paling penting selain menjadi isteri dari suaminya dia juga berperan sebagai ibu dari anak-anaknya. etos kerja perempuan penambang pasir yang ada Di Kelurahan Ulunggolaka letaknya di lingkungan $\mathrm{V}$ bahwa etos kerja atau semangat kerja yang di miliki perempuan tersebut sangatlah berpengaruh karena dengan pekerjaan ini mereka memiliki peluang besar dalam memenuhi kebutuhan hidupnya dan melihat dari keseharian juga tidak merasakan mengeluh walau pekerjaan ini begitu berat tetapi dengan semangat kerja demi kelurga tidak mengenal lelah. ada beberapa Etos Kerja yang di miliki perempuan penambang pasir dalam membantu menyukseskan proses yang di lalui untuk lebih mencapai tujuan yang maksimal sebagai berikut :

a. Sikap tepat waktu merupakan suatu sifat atau kemampuan yang dimiliki seseorang atau perempuan penambang pasir untuk taat dan bisa mengendalikan diri agar tetap mematuhi aturan yang telah di jalankan . sikap tepat waktu juga 
sikap atau perilaku yang tentunya di harapkan oleh banyak orang juga sangat di butuhkan karena dapat membantu suatu kegiatan agar dapat berjalan dengan lancar sesuai yang di harapkan. Dari pengamatan peneliti, panambang pasir di Kelurahan Ulunggolaka di mana para perempuan tersebut menggunakan waktu sebaik mungkin untuk bisa menghasilkan penghasilan yang obtimal, di lihat dari kesehariannya perempuan penambang pasir sangatlah menggunakan waktu sebaik mungkin karena selain tepat waktu juga mereka harus menaggung jawabkan orderan yang telah di sepakati

b. Kejujuran merupakan sikap yang harus di miliki oleh seseorang di mana kejujuran diikat dengan hati nurani manusia,sikap jujur membuat hidup lebih tentram tanpa ada tekanan dari luar maupun batin kita sendiri dalam kaitan ini ,jujur atau benar dalam perkataan berarti adanya persesuaian perkataan dengan hati nurani dan dengan kenyataan atau realita. Jujur dalam bekerja dan berbuat berarti koherensi dan konsistensi antara perbuatan dan perintah. Jujur dalam bekerja sangatlah penting dalam kehidupan dan juga salah satu sikap yang wajib di miliki setiap orang. hasil pengamatan peneliti bahwa perempuan penambang pasir setelah mengangkut beberapa pasir dengan sendiri menakar hasil pasir yang di angkut setelah itu dari hasil penakarannya mereka mengumpulkan pasir.dan di mana salah satu sikap jujur dari perempuan penambang pasir. jujur dari setiap orang sudah jelas sangatlah penting jadi para perempuan pasir harus menunjukan kejujuran dari sikap kerja yang di lakukan seperti,cara pengambilan pasir dari setiap orderan harus benar-benar sesuai takaran. Terus jika orderan sudah ada para perempuan pasir harus memberi tahu bahwa selanjutnya orderan sekian rek sehingga adanya kerja sama dengan kejujuran setiap pengambilan pasir.

c. Sikap Mau Bekerja Sama adalah sikap di mana individu-individu yang bersangkutan mempunyai kepentingan dan kesadaran yang sama untuk mau bekerja sama dalam mencapai tujuan dan kepentingan bersama menjadi suatu kebutuhan untuk mewujudkan keberhasilan dalam mencapai tujuannya. Kerja sama tim bisa menjadi sebuah dorongan sebagai energi ataupun motivasi bagi setiap individu yang tergabung dalam tim kerja tersebut apa bila kerja sama tim bisa berjalan baik, maka kelancaran dalam komunikasi dan rasa tanggung jawab setiap individu dalam tim akan dapat terbentuk. Jadi, pada saat melakukan kerja sama kita harus menghormati dan menghargai setiap pendapat dari anggota yang lain, hal itu agar kerjasama yang di lakukan bisa berjalan secara harmonis dan baik dari sikap mau bekerja sama di mana para perempuan mampu memenuhi orderan yang ada karena dengan adanya kerja sama bisa menyelesaikan orderan yang di berikan, di mana kerja sama ini 
terpenuhi dari hasil yang telah di lakukan mereka membagi dari hasil orderan adanya kerja sama tersebut mampu meringankan dan selesai tepat waktu Mau bekerja sama tercipta kekompakan yang bisa lebih semangat dalam melakukan pekerjaan.

d. Kesederhanaan adalah suatu pilihan, keputusan untuk menjalani hidup dan fokus pada apa yang benar-benar di butuhkan.makna hidup sederhana sejatinya sangatlah luas,bukan berarti hanya hidup apa adanya saja.kesederhanaan dalam hidup biasanya lebih menekankan pada aspek materi dan gaya hidup, bukan pada usah apa saja yang telah dilakukan seseorang untuk mencapai suatu hal. karena untuk usaha dalam suatu pencapaian hal tertentu usaha tidak boleh sederhana melainkan harus di lakukan secara maksimal mungkin untuk mencapai kesuksesan. Kesederhanaan diri seseorang di mana mereka tidak malu dengan pekerjaan dan tetap bersyukur dalam melakukan pekerjaan tersebut kesederhanann sesorang berpengaruh sikap kerja yang di lakukan apa pun kerja mereka selama pekerjaan yang di kerjakan halal. kesedehanan diri dalam setiap orang bisa juga mempengaruhi kebutuhan keluarga yang di mana tidak mempedulikan kata orang yang lebih baik pekerjaanya

2. Faktor-Faktor

Mempengaruhi Etos Kerja perempuan penambang pasir di kelurahan ulunggolaka.

Adapun faktor-faktor yang mempengaruhi etos kerja di kelurhan ulunggolaka yaitu : a. Agama adalah suatu nilai yang akan mempengaruhi atau menentukan pola hidup para penganutnya. di mana sebagai pedoman hidup manusia dalam kehidupan sehari-hari baik secara individu maupun kelompok. Dilihat juga sebagai sumber aturan cara hubungan manusia dan juga bagaimana mereka mampu bekerja keras dalam memenuhi kebutuhan hidup. perempuan penambang pasir memiliki ajaran agama yang tercipta karena ingin mencapai tujuan dan juga salah satu ajaran yang di miliki tekun dalam bekerja dan agama dianggap dapat membantu mencapai tujuan tersebut

b. Budaya adalah suatu cara hidup yang terdapat pada sekelompok manusia, yang berkembang dan suatu pola hidup yang tumbuh dan berkembang pada sekelompok manusia yang mengatur agar setiap individu mengerti apa yang harus di lakaukan Dan untuk mengatur tingkah laku manusia dalam berinteraksi dengan manusia lainnya. budaya juga di sebut etos kerja yang di mana di lakukan para perempuan penambang pasir terciptanya kerja sama sekelompok dalam upaya menyelesaikan suatu pekerjaan yang di kerjakan.

c. Kondisi lingkungan adalah kondisi fisik yang mencakup keadaan sumber alam seperti tanah,air dan di mana juga dapat di artikan menjadi segala sesuatu yang ada di sekitar manusia dan mempengaruhi 
perkembangan manusia. lingkungan alam yang mendukung atau mempengaruhi warga yang berada di Kelurahan Ulunggolaka juga melakukan usaha atau mengolah dan mengambil usaha kerja para perempuan penambang pasir dan bahakan di situlah salah satu sumber pendapatan untuk turut mencari penghidupan di Kelurahan Ulunggolaka.jadi seperti kita lihat diatas bahwa salah satu yang memicu warga melakukan aktiftas pekerjaan itu karena kondisi lingkungan merupakan bisa di manfaatkan dalam kebutuhan keluarga adanya potensi yang ada di Kelurahan Ulunggolaka mampu memanfaatkan lebih baik lagi dalam kebutuhan keluarga

d. Struktur ekonomi adalah di mana di pergunakan untuk menunjukkan komposisi atau susunan sektor-sektor ekonomi dalam suatu perekonomian sektor yang dominan atau yang diandalkan mempunyai kedudukan paling atas dalam struktur tersebut dan menjadi ciri khas dari suatu perekonomian. Perempuan penambang pasir di Kelurahan ulunggolaka memiliki sektor perekonomian yang menjadi sumber mata pencaharian. Struktur ekonomi adalah tinggi rendahnya etos kerja masyarakat di pengaruhi oleh ada atau tidaknya kebutuhan ekonomi yang mampu memberikan kekuatan dalam bekerja lebih keras untuk mampuh meningkatkan kesejahteraan keluarga jadi struktur ekonomi sangat mempengaruhi kehidupan masyarakat ulunggolaka karena demikian pekerjaan yang di lakukan para perempuan penambang pasir untuk memaksimalkan ekonomi atau kebutuhan sehari-hari

3. Meningkatkan Kesejahteraan Keluarga.

Pekerjaan yang di kerjakan oleh perempuan penambang pasir untuk memenuhi kebutuhan hidup keluarga seperti kita lihat pekerjaan tersebut cukup berat yang di lakukan oleh perempuan, tetapi dengan kebutuhan tidak mencukupi yang memaksa untuk melakukan pekerjaan tersebut Pekerjaan yang di lakukan untuk membantu meningkatkan kesejahteraan keluarga dengan cara membantu para suami dalam bekerja. Kesejahteraan disini merupakan suatu kondisi yang di mana terpenuhi semua kebutuhan fisik material, yang memungkinkan keluarga dapat hidup wajar sesuai dengan lingkungannya. seperti dilihat dari etos kerja perempuan penambang pasir dalam membantu meningkatkan kesejahteraan keluarga di kelurahan ulunggolaka yang di mana bekerja untuk memenuhi kebutuhan keluarga baik kebutuhan primer, sekunder maupun tersier. kebutuhankebutuhan yang seharusnya ada di setiap kelurga maupun lingkungan masyarakat sangat mempengaruhi seberapa kuat dalam melakukan pekerjaan yang sekarang di kerjakan.jadi untuk mendapatkan kesejahteraan keluarga disini alasan yang paling kuat adalah keadaan 
sosial dalam keluarga .keadaan sosial di dalam keluarga dapat di katakan baik atau harmonis ,bila mana ada hubungan yang baik dan benar-benar di dasari ketulusan hati dan rasa kasih sayang antara naggota keluraga manifestasi dari hubungan yang benar-benar didasari ketulusan hati dan rasa penuh kasih sayang, Nampak dengan adanya saling hormatmenghormati, toleransi, saling membatu dan saling mempercayai

\section{KESIMPULAN}

Berdasarkan hasil penelitian yang telah diteliti, maka dapat di simpulkan bahwa sebagai berikut:Etos kerja yang di miliki para perempuan adalah: sikap tepat waktu,Kejujuran,.Sikap mau bekerja sama,dan Kesederhanaan adapun Faktorfaktor yang mempengaruhi etos kerja adalah:Agama, Budaya, Kondisi lingkungan dan Struktur ekonomi

\section{SARAN}

Berdasarkan kesimpulan penelitian yang telah di uraikan di atas, maka penulis memberikan saran kepada Kepala lurah ulunggolaka Memberikan sosialisasi kepada penambang pasir mengenai kawasan tempat mereka bekerja agar mampu menjaga wilayah dangan penambangan yang memperhatikan alam dan di harapkan mampu membuka kesempatan kerja seluas-luasnya sehingga mampu memberikan alternative pekerja bagi perempuan penambang pasir, Perempuan penambang pasir, Perempuan penambang pasir hendaknya membentuk paguyuban yang bisa menjadi wadah untuk menampung aspirasi dan pemecahan masalah yang berkaitan dengan penambang pasir dan hendaknya tidak mengantungkan sumber pendapatan pada sector pertambangan pasir saja, tetapi berusaha mencari alternative pendapatan lain. Dan Suami dari perempuan penambang
pasir.Para suami hendaknya berpartisipasi dalam membantu para isteri melakukan pekerjaan penambang pasir dan tidak membiarkan para isteri dalam pekerjaan yang di kerjakan, dan juga para suami harusnya lebih mengutamakan keluarga dalam memenuhi kebutuhan hidup sehingga tidak menanggung beban banyak oleh para perempuan.

\section{DAFTAR PUSTAKA}

Anoraga, Panji. 2011. Psikologi Kerja.Jakarta :Rineka Cipta.

BKKBN. 1995. Pendidikan Kesejahteraan Keluarga.Jakarta BKKBN

Friedmen. 2010. Keluarga Sejahtera. https://www.academia.edu keluarga sejahtera. di akses pada tanggal 20 juli 2019 pukul 8:00 wita ).

Mongid,Astuti Widi Wahyu Asri.2013. Peran Ibu Rumah Tangga Dalam Meningkatkan Kesejahteraan Keluarga skripsi jurusan pendidikan luar sekolah fakultas ilmu pendidikan Universitas Negeri Semarang.

Santoso,Elisa Nur Siti. 2015 . etos kerja dan kontribusi ekonomi perempuan penambang pasir di kaligarang semarang skripsi jurusan politik dan kewarganegaraan fakultas ilmu sosial universitas negeri semarang

Suseno.2010. etos kerja karyawan dengan kompensasi sebagai variable intervening:Chandra Dwiyanto Di Surabaya 